collagen molecule are separated and each chain adopts a randomly coiled configuration ${ }^{2,3}$. As the content of the pyrrolidine residues increases, presumably the number of pyrrolidine-pyrrolidine links between the glycine residues (which in the latest collagen models appear at every third residue position along each polypeptide chain for stereochemical reasons) also increases, and there is an increasing tendency, at least along short lengths of the poly. peptide chains, for a poly-L-proline II type configuration ${ }^{8}$ to be maintained. In the solid state the poly-L-proline II helix is known ${ }^{8}$ to be left-handed with an exact three-fold screw axis in the chain direction; recent polarimetric studies have shown that this configuration is largely maintained in solution. Aqueous solutions of poly-L-proline II are character. ized by very high lævo-rotatory power $\left([\alpha]^{25} \sim\right.$ $-500^{\circ}$ ).

We wish to thank Prof. J. T. Randall for facilities and advice, and Mr. M. R. Watson for discussion.

R. E. BURGE

R. D. HYNes

Wheatstone Physies Laboratory and

Medical Research Council Biophysics Research Unit, University of London King's College,

Strand, W.C.2.

Aug. 12.

${ }^{1}$ Cohen, C., J. Biophys. Biochem. Cytol., 1, 203 (1955).

Boedtker, H., and Doty, P., J. Amer. Chem. Soe., 78, 4267 (1956).

Doty, P., and Nishihara, T., in 'Recent Advances in Gelatin and Glue. Research', Ed. G. Stainsby, 92 (Pergamon Press, London, 1957). 4 Harrington, W. F., Nature, 181, 997 (1958).

Szent-Györgyi, A. G., and Cohen, C., Science, 126, 697 (1957).

Orekhovich, V. N., Toustanovski, A. A., and Plotnikova, N. E. Biochem. Leningr., 13, 55 (1948).

7 Burge, R. E., and Rynes, R. D., J. Mol. Biol., 1, 155 (1959)

Cowan, P. M., and McGavin, S., Nature, 176, 501 (1955).

\section{Some Improvements in Colorimetric Determination of Elastin}

A METHon was previously developed ${ }^{1}$ for the direct colorimetric estimation of elastin by treating a sample of tissue with orcein. All free stain is removed and elastin hydrolyzed with elastase (pancreatin). The stain which is brought in this way into solution is then photometrically estimated.

The method is reported here with some further improvements that made it possible to determine age variations in the elastin content of human lung ${ }^{2}$ and aorta ${ }^{3}$.

The following reagents are used: (1) 95 per cent ethanol containing $0.1 \mathrm{ml}$. concentrated hydro. chloric acid per $100 \mathrm{ml}$; (2) orcein stock solution: orcein $1 \mathrm{gm}$., anhydrous ethanol $100 \mathrm{ml}$., concentrated hydrochloric acid, $1 \mathrm{ml}$.; (3) before use, dilute $1 \mathrm{ml}$. stock solution with $9 \mathrm{ml}$. reagent 1); (4) glycocoll$\mathrm{NaCl}-\mathrm{NaOH}$ solution (Sörensen buffer), $p \mathrm{H} 9 \cdot 5$ at $38^{\circ} \mathrm{C}$.; (5) 4 per cent pancreatin solution, prepared before use with Sörensen buffer 4). Filter until thoroughly clear.

Defatting and drying the tissues. The tissues (about $1.5 \mathrm{gm}$. fresh weight) are finely minced to 2-mm. particles and washed with water to remove blood. The tissues are then extracted at $40^{\circ} \mathrm{C}$. for $8 \mathrm{hr}$. with 3 changes of $100 \mathrm{ml}$. acetone and dried at $70^{\circ} \mathrm{C}$. for $12 \mathrm{hr}$.

Maceration. The dry matter is finely triturated in a mortar and a sample $30-50 \mathrm{mgm}$. is macerated in a $25 \cdot \mathrm{ml}$. glass-stoppered tube with $10 \mathrm{ml}$. $0 \cdot 1 \mathrm{~N}$ sodium hydroxide at $25^{\circ} \mathrm{C}$. for $8 \mathrm{hr}$. with frequent mixing.

Staining and washing. The tube is centrifuged and the residue suspended twice in $10 \mathrm{ml}$. of acid ethanol (reagent 1) at $38^{\circ} \mathrm{C}$. for $30 \mathrm{~min}$., centrifuged and treated with $20 \mathrm{ml}$. orcein solution (reagent 3 ). Staining is carried out at $25^{\circ} \mathrm{C}$. for $24 \mathrm{hr}$. with occasional stirring, then the mixture is centrifuged and the residue repeatedly washed with $20 \mathrm{ml}$. acid ethanol (reagent 1) at $38^{\circ} \mathrm{C}$. until the free colour is completely removed. A first washing of $2 \mathrm{hr}$., a second of 12 and a third of 5 are generally sufficient. Ethanol is removed by centrifuging and washing the residue with $10 \mathrm{ml}$. of buffer (reagent 4) at $38^{\circ} \mathrm{C}$. for $\mathrm{l} \mathrm{hr}$. The buffer is then replaced by exactly $5 \mathrm{ml}$. of fresh buffer.

Enzymatic digestion and colorimetric estimation. Digestion is carried out by adding to the tube $5 \mathrm{ml}$. of 4 per cent pancreatin solution (reagent 5) and incubating with frequent stirring at $38^{\circ} \mathrm{C}$. for $1 \mathrm{hr}$.

All undigested materials are centrifuged. A slight turbidity due to the pancreatin solution which may persist has no appreciable effect. Optical density is read at $590 \mathrm{~m} \mu$. As a blank in the colorimetry, a control tube with $5 \mathrm{ml}$. buffer and $5 \mathrm{ml}$. pancreatin solution is treated in the same way. Colour is completely stable.

The percentage of elastin in the sample may be obtained from the following formula (previously calculated by a calibration curve with pure elastin $\left.{ }^{1}\right)$ :

$$
\text { Percentage elastin }=\frac{D \times 1540}{P}
$$

where $D$ is optical density and $P$ the dry weight of the sample in mgm.

Istituto Biochimico Italiano,

\section{SCARSELIA}

Via Brembo 65, Milano.

Aug. 10.

I Scarselli, V., Giorn. Biochim., 7, 20 (1958)

V. Boll. Soc. Ital. Biol Sperim 35, 191 (1959).

${ }^{3}$ Scarselli, V., Soc. Ital. Biol, Sperim., 28th National Meeting (1959).

\section{Biosynthesis of Corynomycolic Acid from Two Molecules of Palmitic Acid}

CoRynomycolio acid, $\mathrm{C}_{32} \mathrm{H}_{64} \mathrm{O}_{3}$, m.p. $70^{\circ},[\alpha]_{D}=$ $+7 \cdot 5^{\circ}$ has been isolated from the lipids of Coryne bacterium diphtherice ${ }^{1}$ and $C$. ovis ${ }^{2}$. Its structure (III, $R=\mathrm{H}$ ) has been established by degradation ${ }^{3}$ and confirmed by synthesis: the condensation of two molecules of methyl palmitate $\left(\mathrm{I}, R=\mathrm{CH}_{3}\right)$ in presence of $\mathrm{NaH}$ gives the $\beta$-ketoester (II, $R=\mathrm{CH}_{3}$ ) which is reduced by $\mathrm{NaBH}_{4}$ to a mixture of two diastereaisomers (III, $\left.R=\mathrm{CH}_{3}\right)^{4}$; one of these has been shown to be racemic methyl corynomycolate ${ }^{5}$.

The presence of free palmitic acid and of palmitone (IV $)^{6}$ in the lipids of $C$. diphtherice as well as previous work on the mycolic acids of Mycobacteriæ? suggested that corynomycolic acid (III, $R=\mathrm{H}$ ) is formed in vivo by the condensation of two molecules of palmitic acid (probably as palmitoyl-coenzyme $A$ ) and reduc. tion of the intermediate $\beta$-ketoester (II). Palmitone (IV) could be formed through saponification and decarboxylation of the $\beta$-ketoester (II) ${ }^{8,9}$.

The following experiments seem to prove that corynomycolic acid is, in fact, synthesized in vivo from two molecules of palmitic acid.

C. diphtherioe (strain Parke-Williams 8 ) was grown in $500 \mathrm{ml}$. of Loiseau-Philippe medium containing $10 \mu \mathrm{c}$ (total activity $14.4 \pm 2.0 \times 10^{5}$ counts/minute) of the potassium salt of $1-14 \mathrm{C}$ palmitic acid (specific activity $43 \cdot 1 \pm 6.0 \times 10^{7}$ counts $/ \mathrm{min} . / \mathrm{m}$. mole). After 12 days at $37^{\circ}$, the cells were centrifuged, washed and extracted with alcohol-ether $(1: 1)$. 